논 문

\title{
$\mathrm{Al}-\mathrm{Zn}-\mathrm{Mg}-\mathrm{Cu}$ 발포합금 제조 및 흡음특성에 관한 연구
}

\author{
정승룡 - 허보영 \\ 아이큐브 사업단, ERI, ReCAPT, 경상대학교
}

\section{The Study on Fabrication and Sound Absorption Properties of Al-Zn-Mg-Cu Alloy Foams}

\author{
Seung-reung Jeong, and Bo-young Hur ${ }^{\dagger}$ \\ i-cube center, ERI, ReCAPT, School of materials science and engineering, Gyeongsang National University, Jinju 660-701, Korea
}

\begin{abstract}
Metallic foam has been known as a functional material which can be used for absorption properties of energy and sound. The unique characteristics of $\mathrm{Al}$ foam of mechanical, acoustic, thermal properties depend on density, cell size distribution and cell size, and these characteristics expected to apply industry field. $\mathrm{Al}-\mathrm{Zn}-\mathrm{Mg}-\mathrm{Cu}$ alloy foams was fabricated by following process; firstly melting the $\mathrm{Al}$ alloy, thickening process of addition of $\mathrm{Ca}$ granule to increased of viscosity, foaming process of addition of titanium hydride powder to make the pores, holding in the furnace to form of cooling down to the room temperature. Metal foams with various porosity level were manufactured by change the foaming temperature. Compressive strength of the Al alloy foams was 2 times higher at $88 \%$ porosity and 1.2 times higher at $92 \%$ porosity than pure Al foams. It's sound and vibration absorption coefficient were higher than pure $\mathrm{Al}$ foams and with increasing porosity.
\end{abstract}

Key words : Foam, Compress test, Sound absorption, Al-Zn-Mg-Cu alloy foam.

(Received May 10, 2011 ; Accepted June 20, 2011)

\section{1. 서 론}

발포금속은 내부에 기공을 포함하는 재료이며, 금속재료 분야 에서 대표적인 기능성 신소재로써 경량, 고강도를 가지며 우수 한 에너지 흡수능 및 낮은 열전도도 등의 특성을 가진다[1-2]. 이러한 발포금속은 수송기계 부품, 흡음-방음재, 복합 판넬이나 건축자재(실내장식, 천장재)등 다방면에 적용이 가능하며, 재활용 이 가능하기 때문에 환경문제를 해결할 수 있으며, 금속 재료가 가진 일반적인 특성을 보유하고 있어, 고분자로 제조된 다공질 재질과 비교하여 고온에서 사용 할 수 있는 장점이 있다[3-4].

이러한 발포금속은 기공의 형상에 따라 크게 개기공, 폐기공 발포금속으로 나눌 수 있다[5]. 개기공 발포금속은 각각의 기공 이 연결되어 있는 형태를 지니며, 필터나 열교환기 등에 사용 이 가능하며, 폐기공 발포금속은 각각의 기공이 독립된 형태로 존재하며, 충격흡수재나 흡음재 등의 재료로 사용이 가능하다 [6]. 또한, 제조방법에 따라서 주조법, 분말법, 입자분해법, sputtering등이 있으며, 이 방법들은 기공의 형성방법에 따라 크게 직접 발포법과 간접 발포법으로 다시 나누어진다[7-8]. 직 접 발포법은 용융금속을 직접 처리하는 방법으로 용탕내부에 직접 가스를 분사하거나 발포제를 투입하여 기공을 형성시키며 주로 폐기공의 형상을 가진다. 간접 발포법은 금속 분말을 소
결하여 발포금속을 제조하는 방법이 대표적으로, 발포재의 기공 구조를 미리 결정하는 것으로 추가적인 첨가제가 필요 없는 방 법으로 주로 개기공의 형상을 가지게 된다[8-9]. 이와 같이 발 포금속은 제조 조건 및 모재에 따라 밀도, 크기, 기공 구조 등 이 각기 다르게 나타나며, 최종 형태도 패널이나 블록 형상에 서부터 정형 부품 등 다양하게 제조되고 있다[10].

$\mathrm{Al}$ 발포금속은 비철금속 재료 중 대표적인 경량재료로서 많 은 연구가 진행되고 있으며, 우수한 에너지 흡수능과 경량성을 이용하여 수송기계용 부품 중, 범퍼 등 에너지 흡수 재료에 적 용이 가능하다. 그러나 강도가 다소 낮아 충분한 에너지 흡수 가 어렵다는 단점이 있다. 본 논문에서는 대표적인 고강도 합 금인 $\mathrm{Al}-\mathrm{Zn}-\mathrm{Mg}-\mathrm{Cu}$ 합금을 이용하여 발포금속을 제조하고 압축 강도와 흡음성을 파악하여 앞으로 다양한 발포금속의 제조 및 사용에 활용할 데이터를 측정하며, 순수 $\mathrm{Al}$ 과 비교하여 수송 기계용 부품에 적용 가능성을 확인하고자 한다.

\section{2. 실험 방법}

\section{$2.1 \mathrm{Al}-\mathrm{Zn}-\mathrm{Mg}-\mathrm{Ca}$ 합금의 발포금속의 제조}

본 연구에 사용된 $\mathrm{Al}-\mathrm{Zn}-\mathrm{Mg}-\mathrm{Cu}$ 합금의 조성을 Table 1에 나타내었으며, Fig. 1에 나타낸 제조 장치를 사용하여 점증제

†E-mail : hurby@gnu.ac.kr 
Table 1. The chemical composition of the Al- $\mathrm{Zn}-\mathrm{Mg}-\mathrm{Cu}$ alloy.

\begin{tabular}{cccccccc}
\hline \multicolumn{8}{c}{ Chemical composition (wt\%) } \\
\hline Elements & $\mathrm{Zn}$ & $\mathrm{Mg}$ & $\mathrm{Cu}$ & $\mathrm{Fe}$ & $\mathrm{Ti}$ & $\mathrm{Zr}$ & $\mathrm{Al}$ \\
Composition & 7.26 & 2.07 & 1.69 & 0.11 & 0.04 & 0.12 & Balance \\
\hline
\end{tabular}

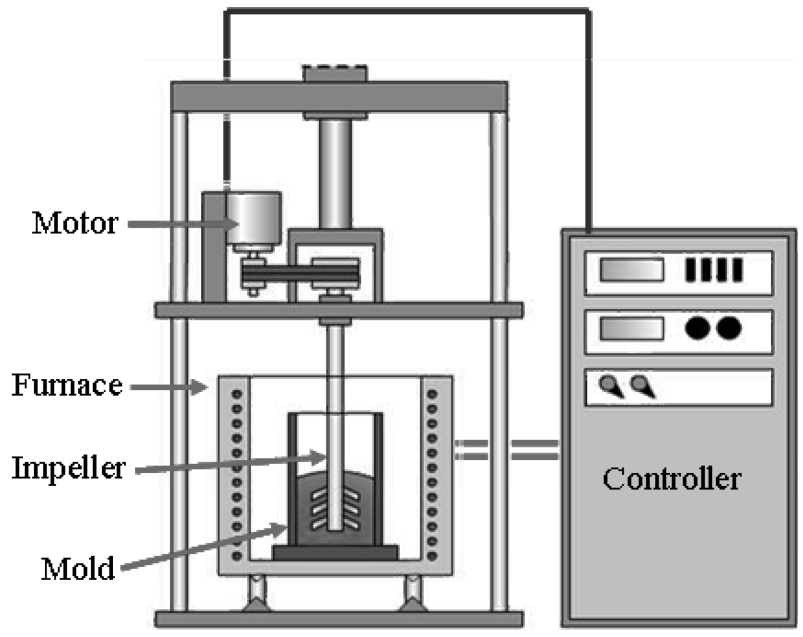

Fig. 1. Schematic diagram of the foaming furnace.

의 양과 발포 온도를 변화시키면서 발포금속을 제조하였다.

발포금속의 제조공정은 용해공정, 점증공정, 발포공정, 유지공 정 그리고 냉각공정의 5단계로 이루어져 있다. 우선 용해공정에 서 $\mathrm{Al}$ 합금을 완전히 용해 한 뒤, 안정화를 위해 30 분간 유지 한 후 점증공정에서 용해 된 $\mathrm{Al}$ 합금의 용탕 내부에 점증제인 $\mathrm{Ca}-\mathrm{Al}$ granule을 첨가하고 임펠러를 회전시켜 용탕 내부에 분 산 교반한다. 점증제를 첨가하여 10 분간 $450 \mathrm{rpm}$ 의 속도로 교 반하여, 적정 점도를 갖게 되면 발포제인 $\mathrm{TiH}_{2}$ 분말 $2.0 \mathrm{wt} \%$ 를 첨가하고 발포제의 분산이 용이하도록 교반기의 속도를 900RPM으로 높여 교반하였다. 발포 교반이 끝난 다음, 임펠러 를 제거하고 형성된 기공이 성장할 수 있도록 60초간 유지한 후, 발포가 진행되는 동안 충격에 의한 기공의 병합과 같은 현 상이 일어나지 않도록 발포금속을 상온에서 안정한 상태로 냉 각하였다. 변수로는 점증제의 양과 발포온도를 달리하여 발포금 속을 제조 하였다. 점증제의 양은 선행 연구를 바탕으로 $1.0 \mathrm{wt} \%, 1.5 \mathrm{wt} \%, 2.0 \mathrm{wt} \%$ 로 결정하였으며[15], 발포 온도가 발 포금속에 미치는 영향을 확인하기 위해 발포 온도를 660,680 , $700^{\circ} \mathrm{C}$ 로 달리하여 발포금속을 제조 하였다.

\section{2 기공 형상 및 조직 관찰}

$\mathrm{Al}$ 발포합금은 4원계 합금계에 $\mathrm{Ca}, \mathrm{Ti}$ 등이 첨가되어 다양한 금속간 화합물을 형성하며 약 150 도 정도의 고액 공존구간을 가지는 등 순 알루미늠과는 다른 성질을 가지며 이에 따라 다 른 기공 구조를 가진다. 발포금속의 단면을 촬영하여, 화상회석 프로그램(i-solution)으로 기공의 크기와 분포도를 측정하였고, 시편의 길이를 측정하여 부피를 계산하고, 무게를 측정하여 상 대밀도를 구하였으며, $\mathrm{Al}$ 합금의 이론 밀도로부터 아래 식을 이 용하여 기공률을 계산하였다.

$$
\operatorname{Pr}(\%)=\left(1-\rho^{*} / \rho_{\mathrm{s}}\right) \times 100
$$

$$
\begin{aligned}
& P r=\text { 발포금속의 기공률 } \\
& \rho^{*}=\text { 발포금속의 밀도 } \\
& \rho_{\mathrm{s}}=\text { 모재의 밀도 }
\end{aligned}
$$

$\mathrm{Al}$ 발포합금의 미세 조직을 관찰하기 위하여 시료를 채취하여 표면을 연마한 후 에칭하여 미세조직과 SEM 조직을 관찰하였다.

\section{3 압축강도 및 경도 측정}

제조되어진 발포금속의 압축강도와 흡수 에너지를 측정하기 위하여 만능재료시험기(Shimadzu AG 10TG, Japan)를 사용하 여 압축시험을 실시하였다. 시험에 사용된 시편의 크기는 size effect를 줄이기 위하여 $30 \mathrm{~mm} \times 30 \mathrm{~mm} \times 30 \mathrm{~mm}$ 의 정육면체 형태로 동일하게 절단하였으며, 발포 온도에 따른 압축강도 및 기공률에 대한 압축강도를 측정하기 위해서 비슷한 기공 구조 를 가지는 시편을 선택하였다. 또한, $\mathrm{Al}$ 발포합금의 발포 온도에 따른 경도 변화를 보기 위해 각 시편 기공벽의 경도를 마이크 로 비커스경도기(Akashi, HM-112)를 사용하여 측정하였다. 시 편 기공벽의 두께가 매우 얇기 때문에 변형을 방지하고자 시편 을 수지로 마운팅하여 기공벽을 고정시킨 상태에서 경도측정을 실시하였으며, 10 회 측정하여 최대값과 최소값을 제거하고 평균 값을 도출하였다.

\section{4 흡음성 측정}

발포금속의 대표적인 특성중 하나인 흡음성을 측정하기 위하 여 Fig. 2와 같이 인피던스관형 시험기(Acoustic Duct)를 이용 하여 직경 $100 \mathrm{~mm}$ 두께 $10 \mathrm{~mm}$ 의 시편의 흡음성을 측정 하였 다. 또한, Air gap module을 조절하여 시편 뒤쪽의 공기층의 두께를 달리하여 그에 따른 흡음성을 측정하였다. 같은 기공률 을 지니는 순 $\mathrm{Al}$ 과 $\mathrm{Al}$ 발포합금 시편을 준비하여 진행하였으며, 실험의 신뢰성을 높이기 위하여 시편을 인피던스관에 최대한 밀 착되게 삽입하여 Air gap 조절시 시편의 움직임이나 외벽을 통 한 소리의 직접적인 통과를 방지하여 진행하였다.

\section{3. 결과 및 고찰}

\subsection{Al-Zn-Mg-Cu합금 발포금속의 점증제 첨가량의 영향} $\mathrm{Al}$ 발포합금의 제조에 있어서 점증제 영향에 대해서 알아보기 위해 점증제의 첨가량을 달리하여 발포금속을 제조하였다. Fig. 3 은 점증제인 $\mathrm{Ca}-\mathrm{Al}$ granule의 첨가량을 달리하였을 때 제조된 시편의 단면 사진을 나타낸 것이며, (a)는 $\mathrm{Ca}-\mathrm{Al}$ granule의 첨 가량이 $1.0 \mathrm{wt} \%$ 인 발포금속의 단면사진이며, $(\mathrm{b})$ 는 $1.5 \mathrm{wt} \%$ 그

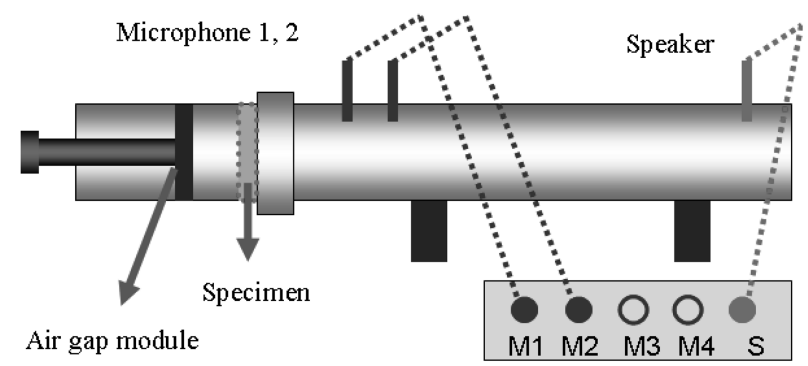

Fig. 2. Apparatus for sound absorption test - Acoustic Duct. 


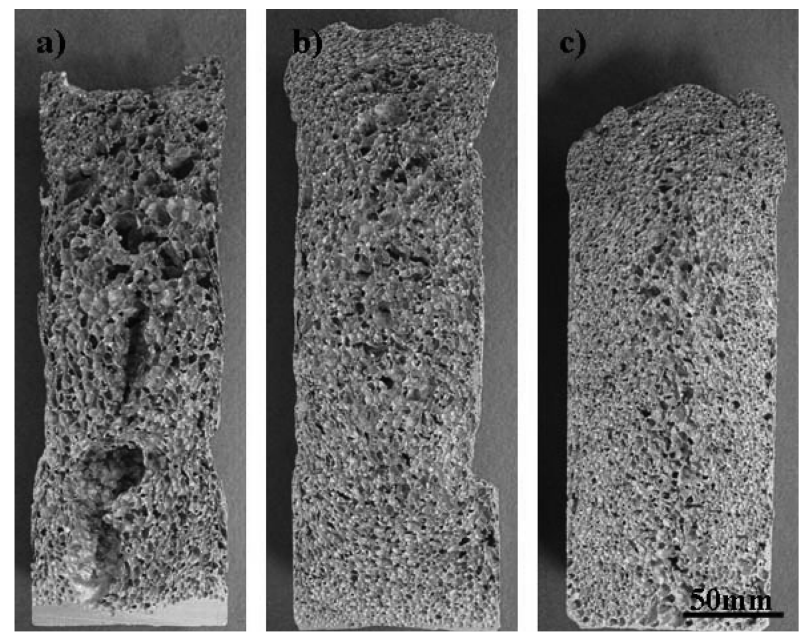

Fig. 3. Photos of Al-Zn-Mg-Cu foam with variation of thickening agent. (a) $1.0 \mathrm{wt} \%$, (b) $1.5 \mathrm{wt} \%$ and (c) $2.0 \mathrm{wt} \%$.

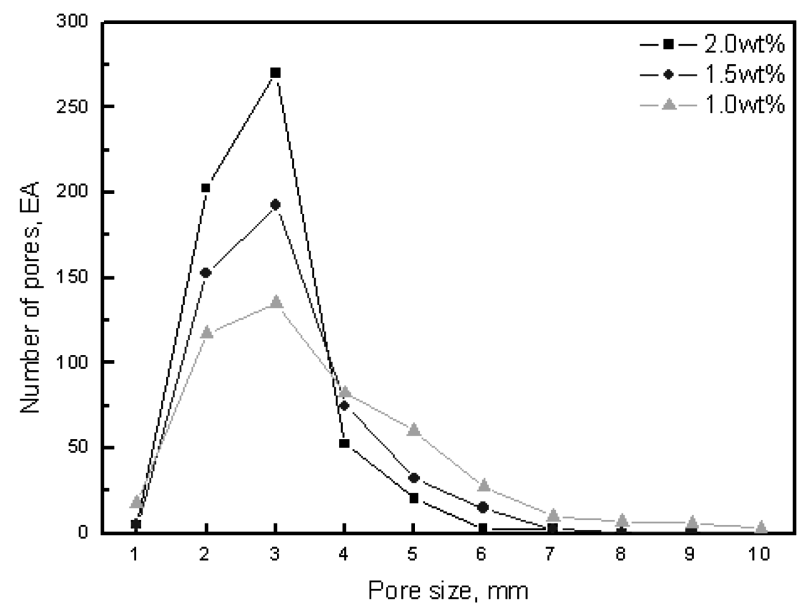

Fig. 4. Cell size distribution of $\mathrm{Al}-\mathrm{Zn}-\mathrm{Mg}-\mathrm{Cu}$ alloy with variation thickening agent.

리고 (c)는 $2.0 \mathrm{wt} \%$ 의 점증제를 투입하여 $680^{\circ} \mathrm{C}$ 에서 발포시킨 시편을 나타내고 있다. 발포금속 내부에 기공을 유지하기 위해 점증제를 투입하여 교반하여 용탕 내부의 점도를 항상시키는데, 일부 합금계에 투입되는 점증제의 양과 교반시간에 대하여서는 선행연구[11-12]에 발표하였으며, 이를 바탕으로 본 연구의 점증 제에 대한 변수 조건을 설정 하였다. $2.0 \mathrm{wt} \% \mathrm{Ca}-\mathrm{Al}$ granule을 첨가하여 만들어진 발포금속의 경우가 가장 건전한 기공의 구조 를 나타 내었으며, $1.0 \mathrm{wt} \%$ 와 $1.5 \mathrm{wt} \% \mathrm{Ca}-\mathrm{Al}$ granule이 첨가된 경우에는 외부 스킨이 불균하게 나타났으며, 가운데 부분의 병 합된 큰 기공이 관찰된다. 이는 순수 알루미늄에 비해 $\mathrm{Al}$ 합금이 높은 표면 장력과 점도를 지니지만 넓은 고액 공존 구간을 가 지므로 응고 과정에서 다소 긴 시간이 소모되므로 그에 따른 유동이 추가적으로 발생 한다. 반면, $3.0 \mathrm{wt} \%$ 이상의 $\mathrm{Ca}-\mathrm{Al}$ granule을 첨가시 높은 $\mathrm{Ca}$ 함량에 따라 금속간 화합물의 양 및 산화물의 양 증가하여 재료의 본래 강도 보다 높은 강도를 나 타내며 응력의 전파 시 불균일한 응력 변화를 나타낸다[13]. $1 \mathrm{wt} \%$ 와 $1.5 \mathrm{wt} \%$ 의 Ca-Al granule을 첨가한 발포금속의 경우
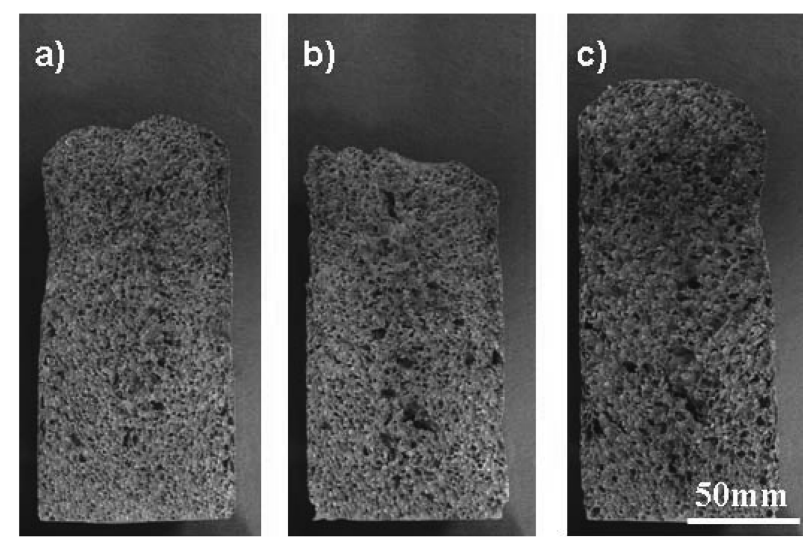

Fig. 5. Photos of $\mathrm{Al}-\mathrm{Zn}-\mathrm{Mg}-\mathrm{Cu}$ foams with variation thickening agent. (a) $660^{\circ} \mathrm{C}$, (b) $680^{\circ} \mathrm{C}$ and (c) $700^{\circ} \mathrm{C}$.

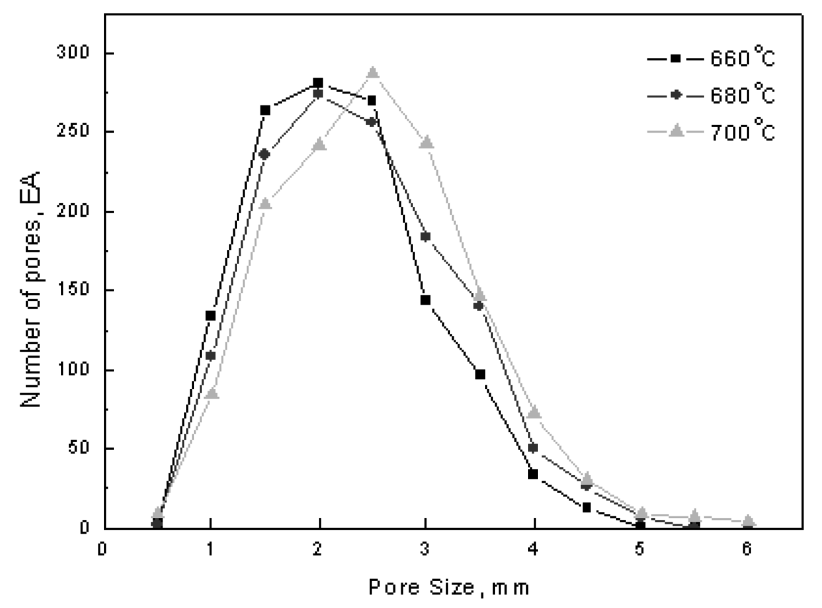

Fig. 6. Cell size distribution of $\mathrm{Al}-\mathrm{Zn}-\mathrm{Mg}-\mathrm{Cu}$ alloy with variation foaming temperature.

는 충분한 점도를 확보하지 못하여 밑 부분에 기공벽이 두꺼 워지고 주괴부가 남는 현상이 관찰되었다[14].

Fig. 4는 점증제량에 따른 기공의 분포를 나타낸 것이며, 점 증제량이 증가 할수록 기공의 크기기 작아지며 더 균일한 것을 알 수 있다. 이는 기공 형성 시 점증제의 첨가로 점도가 향상 되어서 기공이 병합되어 불균일해 지는 것을 막기 때문이다[15].

\subsection{Al-Zn-Mg-Cu발포합금에 미치는 온도의 영향}

발포온도의 변화에 따른 발포금속의 형상변화를 알아보기 위 하여 점증제량을 $2 \mathrm{wt} \%$ 로 고정하고, $660^{\circ} \mathrm{C}, 680^{\circ} \mathrm{C}, 700^{\circ} \mathrm{C}$ 의 온도조건에서 발포금속을 제조하였으며, 그 단면 형상을 Fig. 5 에서 나타내었다. 발포 온도가 증가함에 따라 발포금속의 기공 크기와 기공률이 증가 하였으며 중앙부에 부분적인 찟어짐 현 상이 나타나는 것을 관찰 할 수 있다. 이러한 현상은 발포온도 가 상승 할수록 액상이 고상으로 변하는데 시간이 걸리므로 이 에 따른 용탕의 유동으로 인해 외각부로 잔류 용탕이 이동하면 서 발생된다. 또한 기공의 성장이 오래 진행되어 평균 기공 크 기 및 큰 기공이 분포하는 것을 Fig. 6에서 관찰 할 수 있다. 압축시험을 위한 시편을 Fig. 7에 나타내었으며, 각각의 온도에 대한 기공률 기공의 크기 기공 벽의 두께를 Table 2에 나타내 

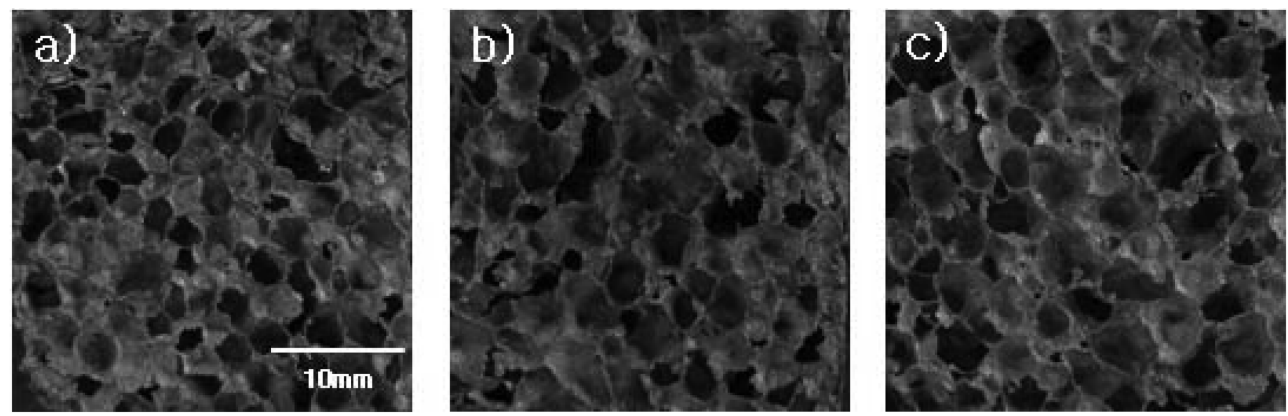

Fig. 7. Photo of Al-Zn-Mg-Cu foams with variation foaming temperature. (a) $660^{\circ} \mathrm{C}$, (b) $680^{\circ} \mathrm{C}$ and (c) $700^{\circ} \mathrm{C}$.

Table 2. Conditions of the each specimens.

\begin{tabular}{cccc}
\hline Mark & Porosity & Average pore size & $\begin{array}{c}\text { Average cell } \\
\text { thickness }\end{array}$ \\
\hline (a) & $86 \%$ & $2.04 \mathrm{~mm}$ & $174 \mu \mathrm{m}$ \\
(b) & $88 \%$ & $2.22 \mathrm{~mm}$ & $142 \mu \mathrm{m}$ \\
(c) & $91 \%$ & $2.64 \mathrm{~mm}$ & $98 \mu \mathrm{m}$ \\
\hline
\end{tabular}

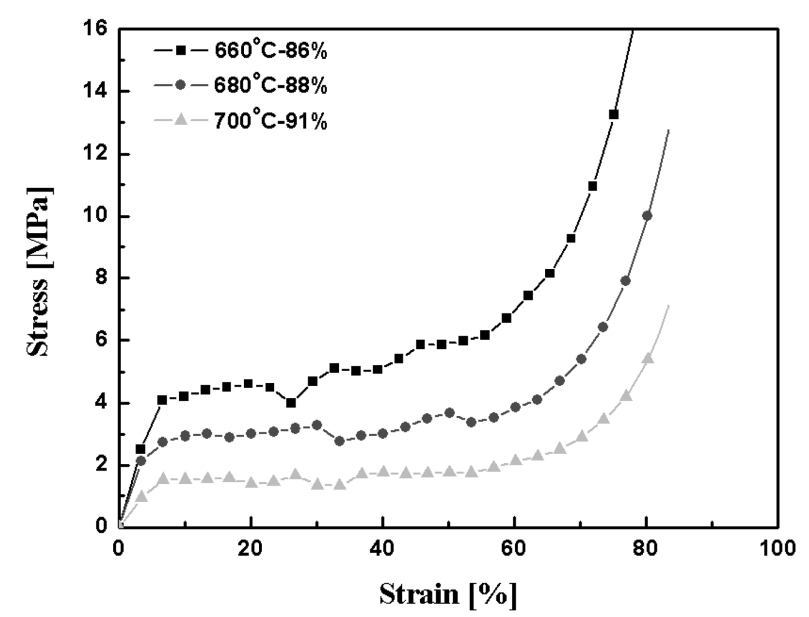

Fig. 8. The results of compression test for the Al-Zn-Mg-Cu alloy foam with variation forming temperature.

었다. Table 2에서 온도가 상승함에 따라 기공률 및 기공의 크 기는 증가 하였으며, 기공 벽의 두께는 감소함을 알 수 있다 [16]. 이는 온도가 증가할수록 표면장력이 감소하고 점도는 증가 하여 기공의 크기가 커져 기공의 벽이 얇아져도 기공을 유지하 기 때문이다. 온도를 증가하며 제조된 시편은 $86 \%, 88 \%, 91 \%$ 의 기공률을 가지며 각각의 기공률에서 $30 \times 30 \times 30 \mathrm{~mm}$ 로 시 편을 컷팅하여 압축시험편을 제조 하였다. 각 시편에 대하여 $10^{-3} \mathrm{~m} / \mathrm{min}$ 의 속도로 실험한 결과는 Fig. 8 와 같으며 계산을 통하여 각각온도별 기공률별 에너지 흡수능을 Fig. 9에 나타내 었다. 두 그림의 항복 응력과 평탄구간의 응력값, $70 \%$ 압축 하 였을 경우 흡수 에너지 값을 정리하여 Table 3에 나타내었다. 일반적인 발포알루미늄과 동일하게 $\mathrm{Al}$ 발포합금의 경우에도 기공 률이 증가 할수록 압축강도 및 에너지 흡수능 또한 감소하는 것을 알 수 있으며 $660^{\circ} \mathrm{C}$ 에서 제조된 시편이 $700^{\circ} \mathrm{C}$ 에서 제조 된 시편에 비해 3.3 배정도 높은 흡수 에너지를 가지는 것을

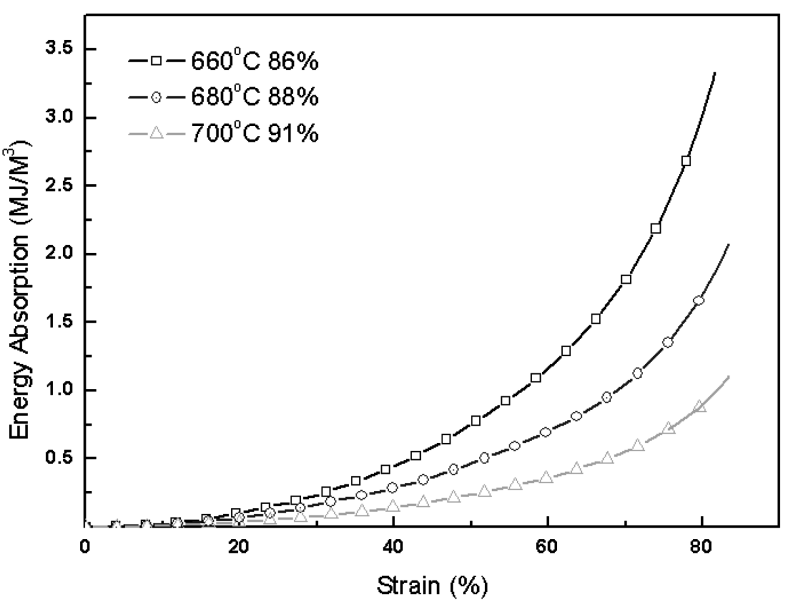

Fig. 9. The results of energy absorption test for the Al- $\mathrm{Zn}-\mathrm{Mg}-\mathrm{Cu}$ alloy foam with variation forming temperature.

Table 3. The results of compression test with variation forming temperature.

\begin{tabular}{cccc}
\hline $\begin{array}{c}\text { Foaming } \\
\text { temperature }\end{array}$ & $\begin{array}{c}\text { Initial peak } \\
\text { stress }\end{array}$ & Plateau stress & $\begin{array}{c}\text { Energy } \\
\text { absorption }\end{array}$ \\
\hline $660^{\circ} \mathrm{C}$ & $4.15 \mathrm{MPa}$ & $4.81 \mathrm{MPa}$ & $1.80 \mathrm{MJ} / \mathrm{m}^{3}$ \\
$680^{\circ} \mathrm{C}$ & $2.61 \mathrm{MPa}$ & $3.08 \mathrm{MPa}$ & $1.04 \mathrm{MJ} / \mathrm{m}^{3}$ \\
$700^{\circ} \mathrm{C}$ & $1.51 \mathrm{MPa}$ & $1.74 \mathrm{MPa}$ & $0.54 \mathrm{MJ} / \mathrm{m}^{3}$ \\
\hline
\end{tabular}

알 수 있었으며, 이를 기초로하여 적정 항복강도와 흡수 에너 지를 가지는 발포금속의 제조가 가능하리라 판단된다[17].

\subsection{Al-Zn-Mg-Cu합금과 순 Al 발포금속간의 특성 비교}

$\mathrm{Al}$ 합금과 순 $\mathrm{Al}$ 의 물성치 비교를 위하여 각각의 발포금속중 기공률 $88 \%$ 와 $92 \%$ 의 시편을 Fig. 10 과 같이 각각의 기공률 및 평균 기공 크기를 측정 하여 Table 4에 나타내었다. 이들 시편은 각 시편별 편차를 줄이기 위하여 각각의 기공률과 기공 의 크기가 유사한 시편을 준비하였다. 각각의 시편을 $10^{-3} \mathrm{~m} /$ $\min$ 의 속도로 압축 실험한 결과를 Fig. 11에 나타내었으며, $\mathrm{Al}-\mathrm{Zn}-\mathrm{Mg}-\mathrm{Cu}$ 합금 발포금속이 순 $\mathrm{Al}$ 발포금속에 비해 높은 강 도를 나타내었다. $88 \%$ 의 기공률을 가지는 시편의 경우 순 $\mathrm{Al}$ 발포금속 보다 Al발포합금이 2배의 강도 향상을 나타내었으나, $92 \%$ 의 기공률을 가지는 시편의 경우는 약 $20 \%$ 의 강도가 향상 되었다. 이는 기공률 $88 \%$ 의 발포금속에 비해 $92 \%$ 의 기공률을 


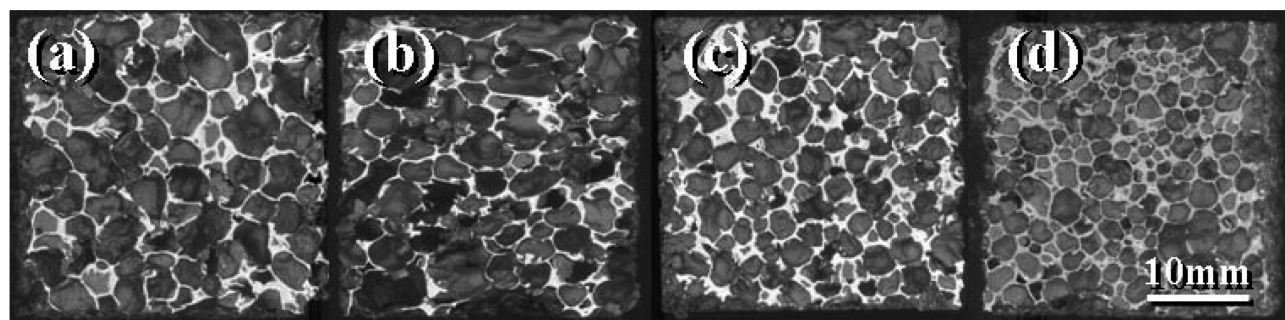

Fig. 10. Scanned images of the compressive specimens test. (a) Al-Zn-Mg-Cu foam- $92 \%$, (b) Pure Al foam- $92 \%$, (c) Al- $\mathrm{Zn}-\mathrm{Mg}-\mathrm{Cu}$ foam- $88 \%$ and (d) Pure Al foam- $88 \%$.

Table 4. The results of porosity and average pore size measurement.

\begin{tabular}{cccc}
\hline Mark & Material & Porosity & Average pore size \\
\hline (a) & Al-Zn-Mg-Cu alloy & $92 \%$ & $3.02 \mathrm{~mm}$ \\
(b) & Pure Al & $92 \%$ & $2.86 \mathrm{~mm}$ \\
(c) & Al-Zn-Mg-Cu alloy & $88 \%$ & $2.24 \mathrm{~mm}$ \\
(d) & Pure Al & $88 \%$ & $1.83 \mathrm{~mm}$ \\
\hline
\end{tabular}

가지는 시편에서 조직이 강도에 미치는 효과가 적어지기 때문 이다. 또한 Fig. 10에서 관찰할 수 있듯이 기공의 구조 역시 $92 \%$ 의 발포 금속에 비하여 $88 \%$ 의 기공률을 가지는 발포금속 이 기공의 구조가 조밀하고 작은 것을 알 수 있다. 이를 통하 여 높은 기공률을 가지는 발포금속의 경우 모재의 성분 등 조 직이 기계적 강도에 미치는 영향보다 기공의 구조가 가지는 영 향이 더 큰 것을 알 수 있고 이러한 경향은 기공률이 증가 할 수록 더 커지는 것을 알 수 있다. Fig. 12의 경도 측정 결과 역시 조성이 동일한 발포금속일 경우 경도의 값은 크게 차이가 나지 않는 것을 알 수 있다.

또한 Fig. 13의 흡음성 실험결과에서도 순 Al보다 합금 발 포금속이 높은 흡음성을 나타내었다. 시편 뒤의 air gap을 조절 할 경우 흡음대역의 변화는 전체 적으로 동일한 경향을 나타내 었으며 이는 시편 뒤의 공간에서 반향 되는 소리의 주파수가 각기 다르기 때문이다. 순수 알루미늄 발포금속보다 Al-Zn-Mg$\mathrm{Cu}$ 합금에서 더 높은 흡음률을 보이는 이유는 Fig. 14의 조직 사진에서 알 수 있듯이 합금 발포금속의 경우 표면에 더 많은 산화물 및 금속간 화합물이 존재하여 순 $\mathrm{Al}$ 발포금속보다 표면 적이 넓어지고 미세 균열 등이 관측되어 시편을 통과하는 과정

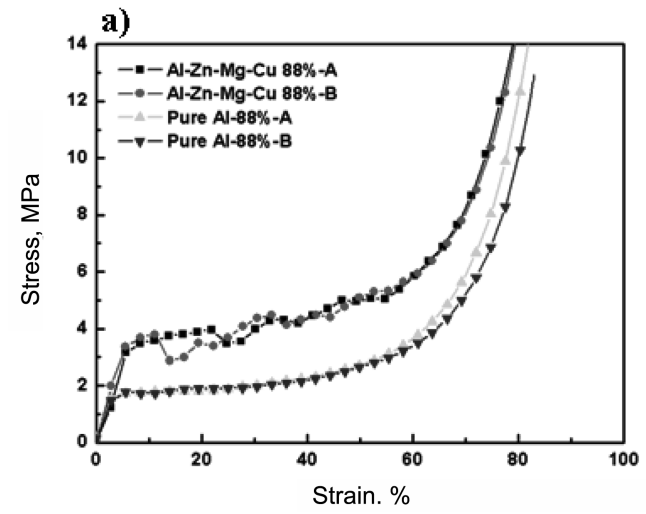

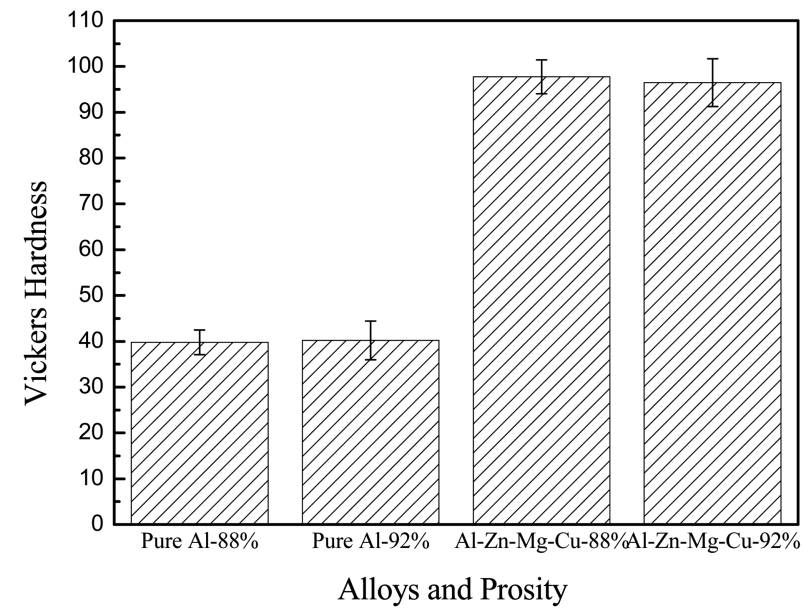

Fig. 12. The result of Vickers Hardness test of Al foam and Al-Zn$\mathrm{Mg}-\mathrm{Cu}$ foam.

에서 소리의 소실이 더 많아졌기 때문이다.

\section{4. 결 론}

주조 발포법을 통하여 $\mathrm{Al}-\mathrm{Zn}-\mathrm{Mg}-\mathrm{Cu}$ 합금을 발포금속을 제 조 하였으며, 그 결론은 다음과 같다.

1) 발포온도의 증가함에따라 기공률이 증가 하였으며, 압축강 도와 흡수 에너지는 감소하였다.

2) $88 \%$ 와 $92 \%$ 의 기공률을 가지는 $\mathrm{Al}-\mathrm{Zn}-\mathrm{Mg}-\mathrm{Cu}$ 합금과 순 알루미늄 발포금속간의 강도를 비교 한 결과, 합금 발포금속이 각각 $100 \%$ 와 $20 \%$ 향상된 강도를 나타내었다.

\section{b)}

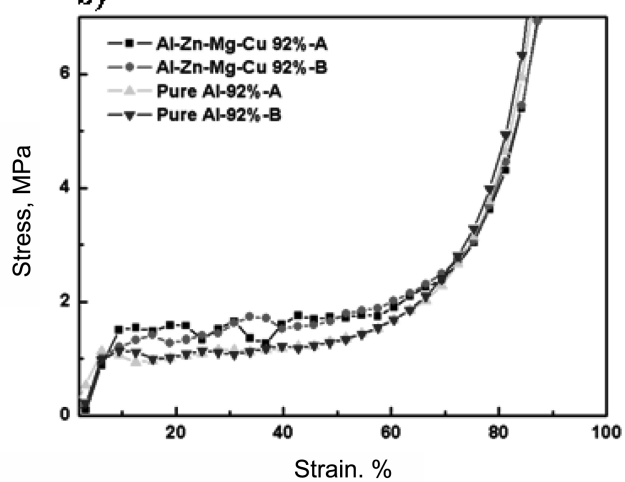

Fig. 11. Compressive test results of Pure $\mathrm{Al}$ and $\mathrm{Al}-\mathrm{Zn}-\mathrm{Mg}-\mathrm{Cu}$ alloy foams; (a) $88 \%$ porosity, (b) $92 \%$ porosity. 

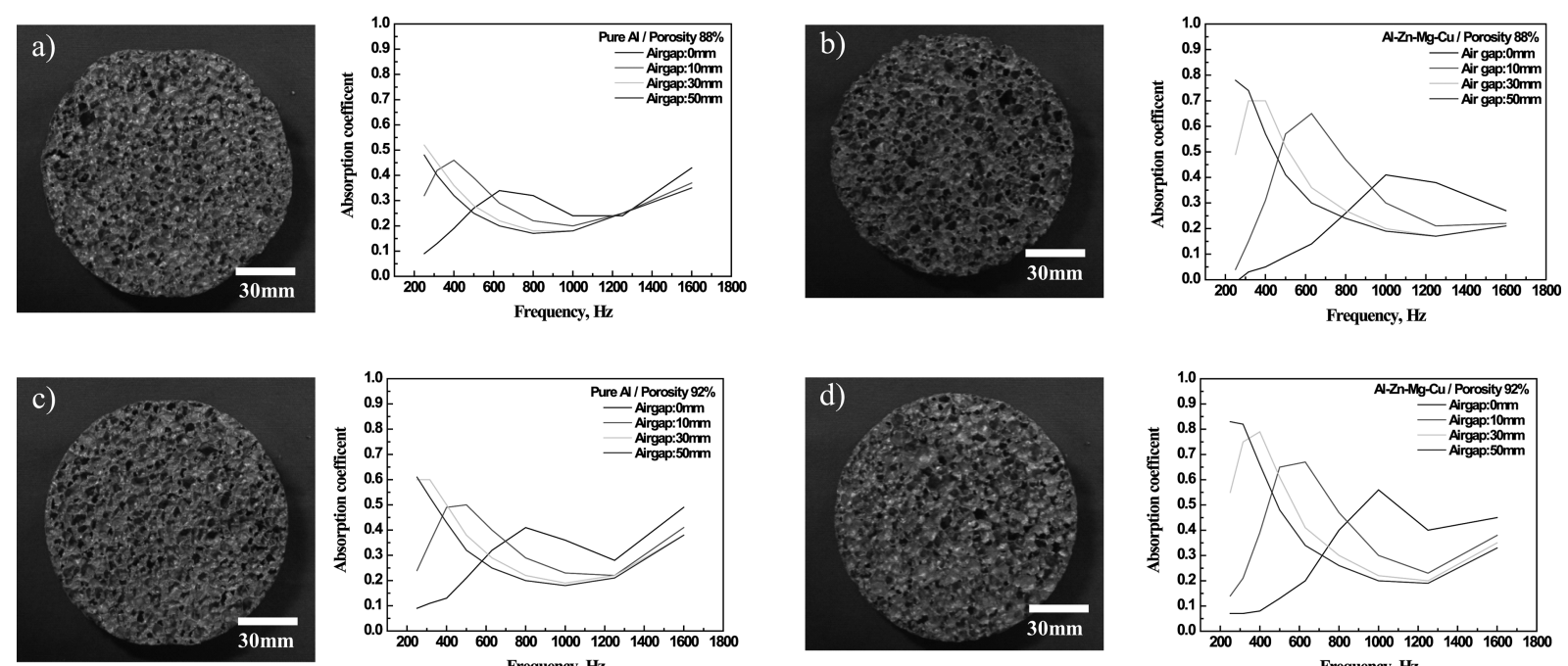

Fig. 13. The results of sound absorption test and absorption coefficient at each frequency. (a) $88 \%$ pure $\mathrm{Al}$ foam, (b) $88 \% \mathrm{Al}-\mathrm{Zn}-\mathrm{Mg}-\mathrm{Cu}$ foam, (c) $92 \%$ pure $\mathrm{Al}$ foam and (d) $92 \% \mathrm{Al}-\mathrm{Zn}-\mathrm{Mg}-\mathrm{Cu}$ foam.
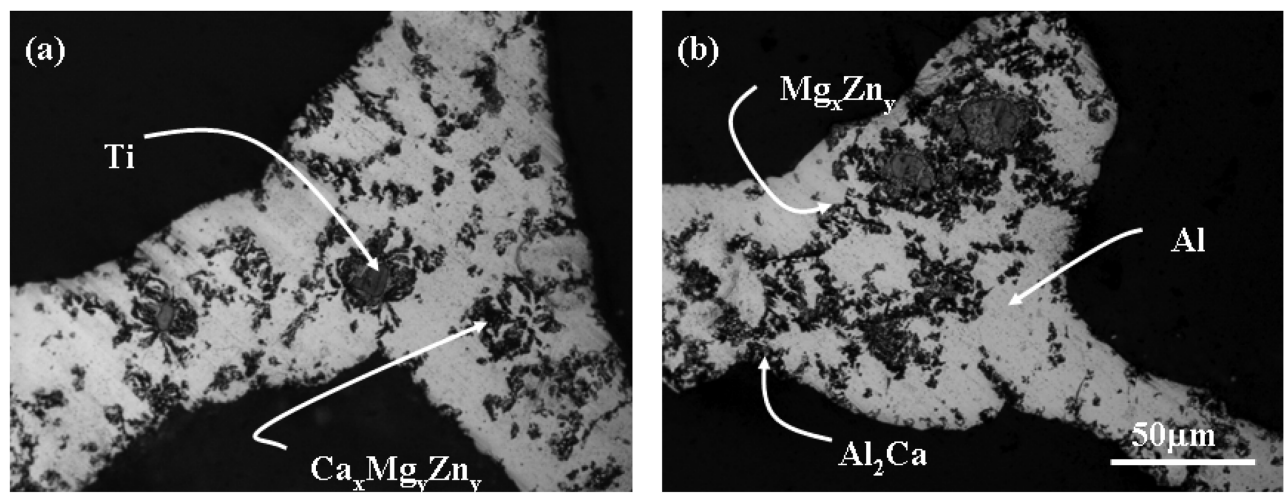

Fig. 14. The OM image of cell wall in Al-Zn-Mg-Cu alloy.

3) 흡음성 시험을 통하여 발포금속의 흡음능력을 측정 한 결 과, $\mathrm{Al}-\mathrm{Zn}-\mathrm{Mg}-\mathrm{Cu}$ 합금 발포금속의 경우 순 $\mathrm{Al}$ 발포금속에 비 하여 높은 흡음성을 나타내었으며 air-gap이 증가할수록 낮은 대역에서의 흡음률이 높아졌다.

\section{감사의 글}

이 논문은 2011년도 정부(교육과학기술부)의 재원으로 한국 연구재단의 기초연구사업 지원을 받아 수행된 것임(20110006156).

\section{참고문헌}

[1] L.J. Gibson, M.F. Ashby; Cellular solids, 2nd ed...Cambridge University Press, (1997) 3-11

[2] T.I. Wu. J.K. Wu; Chemistry and Physics, 74 (2002) 5-12

[3] R. J. Elias, H. L. Corso, J. L. Gervasoni; Hydrogen Energy, 27 (2002) 91-97

[4] S.K. Hyun, H. Nakajima; Fabrication of Lotus-Structured. Porous Iron by Unidirectional Solidification under Nitrogen Gas, Advanced Engineering Materials, 4 (2002) 741-744
[5] KS, KS D 0080, "Glossary of terms used in metal foams", (2010)

[6] J. Banhart, M.F. Ashby and N.A. Fleck; Cellular Metals and Metal Foaming Technology, Verlag MIT Publishing, (2001) 63-68

[7] B.Y. Hur, H.J. Ahn, D.C. Choi, S.H. Cho, K.D. Park, Y.J. Kim and S.H. Jun; Proceeding of the Symposium on Solidification Process of Metals, (2000) 87

[8] J. Banhart; Metal foams; Production and Stability, Advanced Engineering Materials, 9 (2006) 781-794.

[9] G. Kaptay; Interfacial criteria for stabilization of liquid foams by solid particles, Colloid Surface A, Physicam. Eng. Aspects, 230 (2004) 67-80

[10] J. Banhart; Manufacture, characterisation and application of cellular metals and metal foams, Prog. Mater. Sci. 46 (2001) 559-632

[11] S.H Park; Influence of Alloying Elements on Rheological Behavior of Molten Aluminum Alloys, Doctor, Gyeongsang national university, Korea (2008)

[12] S.H Park, S.Y Kim, D.K Ahn, D.I Ha, S.H Jo, S.C Bae, B.Y Hur; A Study on the Viscosity and Surface Tension for Foaming Materials and the Effects of Addition Elements, Kor. J. Mater. Res., 12(6), (2002) pp. 729-734 
[13] S.H. Park, Y.S. Um, C.H. Kum and B.Y. Hur; Thermophysical Porperties of $\mathrm{Al}$ and $\mathrm{Mg}$ alloys for Metal Foam Fabrication, Colloids and Surfaces A: Physicochemical and Engineering Aspects, 263 (2005) 280-283

[14] B.Y Hur, S.H Park, M.H Jang, H.J Park; A study on Surface Tension of Molten Aluminum Alloys, J. KAIARI , 3(2) (2003) pp. 23-30

[15] T. Miyoshi, M. Itoh, S. Akiyama and A. Kitahafa; ALPORAS Aluminum Foam: Production Process, Properteis and
Applications, Advanced Engineering Materials, 2(4) (2000) 179-183

[16] C.M. Cady, G.T. Gray III, C. Liu, M.L. Lovato and T. Mukai; Compressive properties of a closed-cell aluminum foam as a function of strain rate and temperature, Mat. Sci. Eng. A 525 (2009) 1-6

[17] S.Y Kim; A Study on Fabrication of Lightweight Aluminum Alloy foams and Mechanism of Pore Formation in Melt foaming Process, Doctor, Gyeongsang national university, Korea, (2006) 